\title{
PENGARUH DISIPLIN KERJA, KOMPETENSI DAN PRODUKTIVITAS TERHADAP KEPUASAN KERJA PEGAWAI PADA KOMISI PEMILIHAN UMUM (KPU) PROVINSI SULAWESI TENGAH
}

\author{
Evawarta I. Pagisi \\ eva.nesiad4f@gmail.com \\ (Dosen Fakultas Ekonomi Universitas Alkhairaat)
}

\begin{abstract}
ABSTRAK
Penelitian ini bertujuan untuk mengetahui dan menganalisis pengaruh disiplin kerja, kompetensi, dan produktivitas terhadap kepuasan aparatur di Komisi Pemilihan Umum Provinsi Sulawesi Tengah. Populasi terdiri dari 46 pejabat yang semuanya dipilih sebagai responden melalui teknik sensus. Alat analisis adalah regresi linier berganda. Hasil penelitian menunjukkan bahwa disiplin kerja, kompetensi, dan produktivitas secara simultan berpengaruh signifikan terhadap kepuasan pegawai KPU dengan nilai kuadrat 0,548 atau $54,8 \%$ yang menunjukkan bahwa kepuasan pegawai dipengaruhi pengaruh disiplin kerja, kompetensi, dan produktivitas. sebesar $54,8 \%$, sedangkan unsur kepuasan sisanya dipengaruhi oleh variabel lain yang tidak diteliti. Secara parsial disiplin kerja dan produktivitas berpengaruh signifikan terhadap kepuasan. Sedangkan produktivitas berpengaruh tidak signifikan terhadap kepuasan pegawai di Komisi Pemilihan Umum Sulawesi Tengah dengan tingkat signifikansi 0,354>0,05.
\end{abstract}

Kata kunci: Disiplin kerja, Kompetensi, Produktivitas, dan Kepuasan Kerja

\section{LATAR BELAKANG}

Berbentuk badan milik negara ataupun milik swasta akan senantiasa baik jika kepuasan kerja yang diperoleh pegawai semakin tinggi. Kepuasan kerja sangat menentukan seberapa baik kinerja dari organisasi itu sendiri, sebab kepuasan bisa diukur dari seberapa baik disiplin pegawainya, kompetensinya serta produktifitas yang dimiliki oleh pegawainya. Salah satu faktor yang dapat mempengaruhi ketidakpuasan dalam bekerja adalah kedisiplinan kerja. Menurut (Umar A, 2019) Kepuasan kerja ditetentukan oleh seberapa besar tingkat kedisiplinan yang dimiliki setiap pegawai, artinya semakin disiplin maka hasil yang diperoleh akan semakin tinggi.

Menurut (Azis, 2019) Disiplin dalam bekerja merupakan faktor yang harus pula dimiliki oleh pegawai yang menginginkan tercapainya kepuasan dalam pekerjaannya. Disiplin kerja dapat berupa ketepatan waktu dalam kerja, ketaatan terhadap tugas-tugas yang diberikan kepadanya, serta pemanfaatan sarana secara baik. Dengan adanya disiplin kerja akan meningkatkan semangat dan kegairahan kerja karyawan yang tinggi ini akan mendorong karyawan untuk bekerja secara lebih produktif sehingga pada gilirannya akan dapat meningkatkan produktivitas kerja karyawan. Paradigma lembaga-lembaga saat ini yang ingin berkembang dan maju sangat membutuhkan pegawai yang berdisiplin tinggi dalam pekerjaannya. Mereka yang mempunyai semangat tinggi, patuh terhadap aturan yang ditetapkan lembaga, kreatif dan dapat memanfaatkan sarana dengan baik akan mampu untuk bersaing dalam kondisi saat ini yang semakin kompetitif (Hasibuan, 2006:193).

Sastrohadiwiryo (2005 : 290) mengatakan bahwa disiplin kerja merupakan salah satu fungsi operatif yang terpenting dan tidak dapat diabaikan karena sebagai bagian dari fungsi pemeliharaan karyawan dan bilamana semakin baik disiplin kerja karyawan, maka semakin tinggi prestasi kerja yang dicapainya.

Indikator disiplin kerja yang digunakan untuk mengukur disiplin kerja dalam penelitian ini adalah menurut Hasibuan (2005:110) adalah sebagai berikut: 
1. Sikap Mental dan perilaku karyawan yang berasal dari kesadaran atau kerelaan dirinya sendiri dalam melaksanakan tugas dan peraturan perusahaaan, terdiri dari:

a. Kehadiran berkaitan dengan keberadaan karyawan ditempat kerja untuk bekerja

b. Mampu memanfaatkan dan menggunakan perlengkapan dengan baik

2. Norma Peraturan tentang apa yang boleh dan apa yang tidak boleh dilakukan oleh para karyawan selama dalam peruahaan dan sebagai acuan dalam bersikap, terdiri dari:
a. Mematuhi peraturan merupakan karyawan secara sadar mematuhi peraturan yang ditentukan perusahaan.
b. Mengikuti cara kerja yang ditentukan perusahaan.

3. Tanggung jawab Merupakan kemampuan dalam menjalankan tugas dan peraturan dalam perusahaan. Menyelesaikan pekerjaan pada waktu yang ditentukan karyawan harus bertanggung jawab atas pekerjaannya dengan menyelesaikan pekerjaan tepat pada waktu yang ditentukan perusahaan.

Menurut (Salim, 2019) Kompetensi dapat diartikan sebagai kemampuan seseorang dalam menghadapi situasi dan keadaan di dalam pekerjaannya. Kompetensi seseorang dapat dilihat dari tingkat kreativitas yang dimilikinya serta inovasi-inovasi yang diciptakan dan kemampuannya dalam menyelesaikan suatu masalah.

Ada lima indikator kompetensi yang harus dimiliki oleh semua individu (Moeheriono, 2009:15) yaitu sebagai berikut:

1. Keterampilan menjalankan tugas (Taskskills), yaitu keterampilan untuk melaksanakan tugas-tugas rutin sesuai dengan standar di tempat kerja.

2. Keterampilan mengelola tugas (Task management skills), yaitu keterampilan untuk mengelola serangkaian tugas yang berbeda yang muncul dipekerjaannya.

3. Keterampilan mengambil tindakan (Contingency management skills), yaitu keterampilan mengambil tindakan yang cepat dan tepat bila timbul suatu masalah di dalam pekerjaan.

4. Keterampilan bekerja sama (Job role environment skills), yaitu keterampilan untuk bekerja sama serta memelihara kenyamanan lingkungan kerja.

5. Keterampilan beradaptasi (Transfer skill), yaitu keterampilan untuk beradaptasi dengan lingkungan kerja yang baru.

Produktivitas kerja itu sendiri terdiri dari dimensi efektivitas dan efisiensi yang mengacu pada pendapat Siagian (1999). Pengertian produktivitas kerja menurut Siagian (1999) “.... harus menampakkan dua dimensi, yaitu dimensi efisiensi dan dimensi efektivitas. Efisiensi yaitu perbandingan yang positif antara hasil yang dicapai dengan masukan yang dipergunakan, artinya suatu tugas dikatakan efisien apabila hasil kerja yang diperoleh lebih besar dari pada pengorbanan yang diberikan dalam bentuk sumber daya insani. Sedangkan efektiv berarti penyelesaian pekerjaan tepat pada waktu yang telah ditetapkan dan tepat sasaran".

Umar (2005:9), menyatakan produktivitas ialah perbandingan antara hasil yang dicapai (output) dengan keseluruhan sumber daya yang digunakan (input)". Konsep produktivitas pada umumnya mengaitkan antara keluaran (ouput) dan masukan (input). Sedangkan menurut whitmore Abdilah (2010:58) produktivitas adalah sebagai suatu ukuran atas penggunaan sumber daya dalam suatu organisasi yang biasanya dinyatakan sebagai rasio dari keluaran (ouput) yang dicapai dengan sumber daya yang digunakan

Menurut Simamora (Rahman, 2019) faktor-faktor yang digunakan dalam pengukuran produktivitas kerja meliputi kuantitas kerja, kualitas kerja dan ketepatan waktu:

1. Kuantitas kerja adalah merupakan suatu hasil yang dicapai oleh karyawan dalam jumlah tertentu dengan perbandingan standar ada atau ditetapkan oleh perusahan.

2. Kualitas kerja adalah merupakan suatu standar hasil yang berkaitan dengan mutu dari suatu produk yang dihasilkan oleh karyawan dalam hal ini merupakan suatu kemampuan karyawan dalam menyelesaikan pekerjaan secara teknis dengan perbandingan standar yang ditetapkan oleh perusahaan. 
3. Ketepatan waktu merupakan tingkat suatu aktivitas diselesaikan pada awal waktu yang ditentukan, dilihat dari sudut koordinasi dengan hasil output serta memaksimalkan waktu yang tersedia untuk aktivitas lain. Ketepatan waktu diukur dari persepsi karyawan terhadap suatu aktivitas yang disediakan diawal waktu sampai menjadi output.

Hasibuan (2005) menyatakan bahwa kepuasan kerja merupakan evaluasi yang menggambarkan seseorang atas perasan sikapnya senang atau tidak puas dalam bekerja.

Tolak ukur kepuasan kerja yang mutlak sulit untuk dicarikarena setiap individu pegawai berbeda standar kepuasannya. Adapun indikatorindikator kepuasan kerja menurut Hasibuan (2001) antara lain:

\section{Kesetiaan}

Penilai mengukur kesetiaan karyawan terhadap pekerjaannya, jabatannya, dan organisasi. Kesetiaan ini dicerminkan oleh kesediaan karyawan menjaga dan membela organisasi di dalam maupun di luar pekerjaan dari rongrongan orang yang tidak bertanggung jawab.

2. Kemampuan

Penilai menilai hasil kerja baik kualitas maupun kuantitas yang dapat dihasilkan karyawan tersebut dari uraian pekerjaannya.

3. Kejujuran

Penilai menilai kejujuran dalam melaksanakan tugas-tugasnya memenuhi perjanjian baik bagi dirinya sendiri maupun terhadap orang lain.

4. Kreatifitas

Penilai menilai kemampuan karyawan dalam mengembangkan kreativitasnya untuk menyelesaikan pekerjaannya, sehingga akan dapat bekerja lebih baik.

5. Kepemimpinan

Penilai menilai kemampuan untuk memimpin, mempunyai pribadi yang kuat, dihormati, berwibawa, dan dapat memotivasi orang lain atau bawahannya untuk bekerja secara efektif.

6. Tingkat Gaji

Penilai menilai jumlah gaji yang diberikan perusahaan dan diterima karyawan harus sesuai dengan apa yang karyawan berikan kepada perusahaan agar mereka merasa puas.
7. Kompensasi tidak langsung

Penilai menilai pemberian balas jasa yang memadai dan layak kepada para karyawan atas kontribusi mereka membantu perusahaan mencapai tujuannya. Pemberian balas jasa atau imbalan atas tenaga, waktu, pikiran serta prestasi yang telah diberikan seseorang kepada perusahaan.

8. Lingkungan Kerja

Penilai menilai lingkungan kerja yang baik dapat membuat karyawan merasa nyaman dalam bekerja.

Berdasarkan uraian permasalahan yang telah dituangkan dalam latar belakang, adapun judul penelitian ini yaitu "Pengaruh Kedisiplinan Kerja, Kompetensi, dan Produktivitas Terhadap Kepuasan Kerja pegawai Pada Komisi Pemilihan Umum (KPU) Propinsi Sulawesi Tengah".

Berdasarkan uraian latar belakang di atas, adapun rumusan masalah ini yaitu sebagai berikut:

1. Apakah disiplin kerja, kompetensi, dan produktivitas secara simultan berpengaruh terhadap kepuasan kerja pegawai pada Komisi Pemilihan Umum (KPU) Pada Propinsi Sulawesi Tengah?

2. Apakah disiplin kerja berpengaruh terhadap kepuasan kerja pegawai pada Komisi Pemilihan Umum (KPU) Pada Propinsi Sulawesi Tengah?

3. Apakah kompetensi berpengaruh terhadap kepuasan kerja pegawai pada Komisi Pemilihan Umum (KPU) Pada Propinsi Sulawesi Tengah?

4. Apakah produktivitas berpengaruh terhadap kepuasan kerja pegawai pada Komisi Pemilihan Umum (KPU) Pada Propinsi Sulawesi Tengah?

\section{METODE}

Metode penelitian yang digunakan dalam penelitian ini adalah metode deskriptif verifikatif. Deskriptif digunakan untuk menggambarkan dan menganalisis hasil penelitian tetapi tidak digunakan untuk membuat kesimpulan yang lebih luas, Sedangkan verifikatif digunakan untuk membuktikan hipotesis melalui perhitungan dan analisis terhadap hasil penelitian dan hasilnya dapat digunakan untuk membuat kesimpulan (Ridwan, 2003).

Penelitian ini dilakukan pada Komisi Pemilihan Umum (KPU) Perwakilan Propinsi 
Sulawesi Tengah, dengan subjek penelitian adalah pegawai yang bekerja dan bertugas di KPU Propinsi Sulawesi Tengah. Adapun waktu penelitian ini adalah bulan Februari s/d Maret 2018.

Jumlah populasi pada penelitian ini sebanyak 33 orang Pegawai Negeri Sipil (PNS) yang terdiri dari DPK sebanyak 16 orang dan Organik seabnyak 17 orang dan 13 honorer sehingga total populasi sebanyak 46 orang pegawai.

Asumsi klasik telah dilakukan dengan benar, selanjutnya perhitungan regresi dengan menggunakan persamaan regresi berganda (Sugiono, 2010). Uji regresi berganda digunakan dalam menjawab permasalahan pertama sampai permasalahan keempat yaitu melihat besarnya pengaruh variable independent (X) terhadap variabel dependent (Y) baik secara simultan maupun secara parsial menurut Umar (2001 : 2009). Uji statistik parametrik Regresi Linier Berganda persamaan formulasinya sebagai berikut:

$$
Y=a+b_{1} X_{1}+b_{2} X_{2}+\ldots \ldots \ldots \ldots+b_{n} X_{n}+\epsilon
$$

Dimana :

$$
\begin{array}{ll}
\mathrm{Y} & =\text { Variabel dependent } \\
\mathrm{a} & =\text { Konstanta } \\
\mathrm{b}_{1}, \mathrm{~b}_{2} \ldots \ldots \mathrm{b}_{\mathrm{x}}= & \text { Kofesien regresi } \\
\mathrm{X}_{1}, \mathrm{X}_{2} \ldots . . \mathrm{X}_{\mathrm{n}}= & \text { Variabel independent } \\
\in & =\text { Residual (kesalahan pengganggu) }
\end{array}
$$

Jika penelitian tersebut di atas dikaitkan dengan penelitian ini maka menjadi :

$$
Y=a+b_{1} X_{1}+b_{2} X_{2}+b_{3} X_{3}+\epsilon
$$

\section{Dimana :}

$\begin{array}{ll}\mathrm{Y} & =\text { Kepuasan Kerja KPU } \\ \mathrm{X}_{1} & =\text { Kedisiplinan Kerja } \\ \mathrm{X}_{2} & =\text { Kompetensi } \\ \mathrm{X}_{3} & =\text { Produktivitas } \\ \mathrm{b}_{1}-\mathrm{b}_{3} & =\text { Koefisien regresi } \\ \in & =\quad \text { Residual } \\ \text { pengganggu). } & \end{array}$

Pengujian hipótesis "Disiplina kerja, kompetensi, dan produktivitas terhadap kepuasan kerja KPU Propinsi Sulawesi Tengah peneliti menggunakan uji statistik yaitu:

1. Koefisien Determinasi
Secara umum besarnya koefisien determinasi simultan $\left(\mathrm{R}^{2}\right)$ yaitu berada antara 0 dan 1 atau $0<$ $\mathrm{R}^{2}<1$. (Ghozali, 2006).

Rumus Koefisien Determinasi $\left(\mathrm{R}^{2}\right)$ adalah (Ghozali,2006)

$$
R^{2}=\frac{\left\{\mathrm{n} \sum x y-\left(\sum x\right)\left(\sum y\right)\right\}^{2}}{\sqrt{\left\{n \sum x^{2}-\left(\sum x^{2}\right)\right\}}\left\{n \sum y^{2}-\left(\sum y\right)^{2}\right\}}
$$

Keterangan :

$\mathrm{R}^{2}=$ Koefisien determinasi

$\mathrm{n}=$ banyaknya sampel

Nilai Koefisien determinasi $\left(\mathrm{R}^{2}\right)$ Total diperoleh dari : e1 persamaan 1, dimana e1= $\sqrt{1-R^{2}} 1$ e2 persamaan 1 , dimana e2 = $\sqrt{1-R^{2}}$ Nilai Koefisien Determinasi $\left(\mathrm{R}^{2}\right)$ Total $: R^{2}=1-\left(\epsilon 1^{2} \times \epsilon 2^{2}\right)$

\section{Uji Simultan (Uji F)}

Dalam mengetahui pengaruh secara simultan variabel independent terhadap variabel dependent, digunakan pengujian statistik uji $\mathrm{F}$ dengan formulasinya menurut Supranto (2000: 27) adalah:

$$
\mathrm{Uji} F=\frac{\mathrm{R}^{2} / \mathrm{K}-1}{\left(1-\mathrm{R}^{2}\right) /(\mathrm{n}-\mathrm{k})}
$$

Dimana :

$\mathrm{F}=$ Diperoleh dari tabel distribusi $\mathrm{F}$

$\mathrm{R}^{2}=$ Koefisien diterminasi berganda

$\mathrm{K}=$ Jumlah variabel independent (bebas)

$\mathrm{n}=$ Jumlah sampel adalah:

Adapun kaidah pengambilan keputusan

a. Jika $F_{\text {hitung }}>F_{\text {tabel }}$ pada tingkat kepercayaan 95\% $(\alpha=0,05)$, maka terbukti semua variabel bebas yang diamati secara serempak berpengaruh nyata terhadap variabel tidak bebas.

b. Jika $F_{\text {hitung }}<F_{\text {tabel }}$ pada tingkat kepercayaan 95\% $(\alpha=0,05)$, maka terbukti semua variabel bebas yang diamati secara serempak tidak berpengaruh nyata terhadap variabel tidak bebas.

\section{Uji Parsial (Uji t)}

Untuk menguji pengaruh variabel independent secara parsial terhadap variabel dependent, maka uji t dengan formulasi menurut Sugiyono (2011) sebagai berikut:

$$
\mathrm{t}_{\text {hitung }}=\frac{\text { bi }-\mathrm{bj}}{\mathrm{Sb} \mathrm{i}}
$$


Dimana :

$\mathrm{t}_{\text {hitung }}=$ Diperoleh dari tabel distribusi $\mathrm{t}$

bi $\quad=$ Koefisien regresi dan

bj = nilai yang dihipotesis

Sbi = Standar kesalahan dari

koefisien $b$

Pengambilan keputusan dilakukan dengan cara sebagai berikut :

a. Jika $F_{\text {hitung }}>F_{\text {tabel }}$ pada tingkat kepercayaan 95\% $(\alpha=0,05)$, maka terbukti variabel independen (X) yang diamati mempunyai pengaruh yang signifikan terhadap variabel dependen $(\mathrm{Y})$.

b. Jika $F_{\text {hitung }}<F_{\text {tabel }}$ pada tingkat kepercayaan 95\% $(\alpha=0,05)$, maka terbukti variabel independen $(\mathrm{X})$ yang diamati tidak berpengaruh signifikan terhadap variabel dependen $(\mathrm{Y})$.

\section{HASIL DAN PEMBAHASAN \\ Hasil Regresi}

Regresi linear berganda merupakan salah satu alat statistik parametrik dengan fungsi menganalisis dan menerangkan keterkaitan antara dua atau lebih faktor penelitian yang berbeda nama melalui pengamatan pada beberapa hasil observasi diberbagai bidang kegiatan. Berkaitan dengan penelitian ini, alat analisis statistik parametrik regresi linear berganda yang digunakan untuk mengetahui pengaruh variabel indevenden (X1,X2 dan X3) terhadap variabel dependen (Y). Dalam konteks penelitian ini regresi linear berganda digunakan untuk mengukur pengaruh disiplin kerja (X1), kompetensi (X2) dan produktivitas (X3) terhadap Kepuasan kerja (Y) pada Komisi Pemilihan Umum (KPU) Provinsi Sulawesi Tengah.

Sesuai hasil analisis regresi linear berganda dengan mengunakan bantuan SPSS For Windos 16,0 diperoleh hasil-hasil penelitian dari 46 orang responden dengan dugaan bahwa terdapat pengaruh antara ketiga variabel independen (disiplin kerja, kompetensi dan produktivitas) terhadap variabel dependen (kepuasan kerja) pada Komisi Pemilihan Umum (KPU) Provinsi Sulawesi Tengah. Hasil perhitungannya dapat diketahui sebagai berikut:
Tabel 1 Perhitungan regresi berganda

\begin{tabular}{|c|c|c|c|}
\hline \multicolumn{5}{|c|}{ Dependen Variabel Y $=$ Kepuasan kerja } \\
\hline Variabel & $\begin{array}{c}\text { Koefisien } \\
\text { regresi }\end{array}$ & $\begin{array}{c}\text { Standar } \\
\text { Error }\end{array}$ & Sig \\
\hline C= Constanta & 9.883 & 12,973 & 0,450 \\
\hline X1 = Disiplin kerja & 0,530 & 0,255 & 0,044 \\
\hline X2 = Kompetensi & 0,134 & 0,143 & 0,354 \\
\hline X3 = Produktivitas & 0,968 & 0,149 & 0,000 \\
\hline \multicolumn{4}{|c}{} \\
R- $=0,740$ \\
$\begin{array}{l}\text { F-Statistik }=16,964 \\
\text { R Square }=0,548 \\
\text { Sig }=0,000\end{array}$ \\
\hline
\end{tabular}

Sumber : Hasil Regresi

Model regresi yang diperoleh dari tabel di atas adalah:

$$
Y=9,883+0,530 X_{1}+0,134 X_{2}+0,968 X_{3}
$$

Persamaan diatas menunjukan bahwa variabel independen yang dianalisa berupa variabel disiplin kerja (X1), kompetensi (X2) dan produktivitas (X3) memberi pengaruh terhadap variabel dependen kepuasan kerja pegawai (Y) model analisis regresi kepuasan kerja pada Komisi Pemilihan Umum (KPU) Provinsi Sulawesi Tengah sebagai berikut:

Dari persamaan diatas dapat dijeleskan:

1. Untuk nilai constanta sebesar 9,883 berarti kepuasan kerja pegawai Komisi Pemilihan Umum (KPU) Provinsi Sulawesi Tengah sebelum adanya variabel independen adalah 9,883 .

2. Disiplin kerja (X1) dengan koefisien regresi 0,530 ini berarti terjadi pengaruh yang positif antara disiplin kerja dengan kepuasan kerja. Artinya semakin baik disiplin kerja yang dimiliki maka akan meningkatkan kepuasan kerja pada Komisi Pemilihan Umum (KPU) Provinsi Sulawesi Tengah.

3. Kompetensi (X2) dengan koefisien regresi 0,134 ini berarti terjadi pengaruh yang positif antara proses kompetensi dengan kepuasan kerja. Artinya apabilah kompetensi ditingkatkan maka akan meningkatkan 
kepuasan kerja pada Komisi Pemilihan Umum (KPU) Provinsi Sulawesi Tengah.

4. Produktivitas (X3) dengan koefisien regresi 0,968 ini berarti terjadi pengaruh yang positif antara produktivitas dengan kepuasan kerja. Artinya apabila Produktivitas ditinggkatkan maka akan meningkatkan kepuasan kerja pada Komisi Pemilihan Umum (KPU) Provinsi Sulawesi Tengah.

Dari Tabel 4.8 dapat dilihat bahwa dari uji deteminasi (kehandalan model) memperlihatkan nilai $\mathrm{R}$ Square $=0,548$ atau $=$ $54,80 \%$. Hal ini berarti bahwa sebesar $54,80 \%$ variabel tidak bebas (Y) dipengaruhi oleh ketiga variabel bebas (X1,X2 dan $\mathrm{X} 3)$, selebihnya dipengaruhi oleh variabel lain diluar penelitian ini.

Selanjutnya berdasarkan Tabel 4.8 dari hasil perhitungan diperoleh $F_{\text {hitung }} 16,964>$ $F_{\text {tabel }} 2,79$ pada taraf nyata $\alpha=0,05$ atau Sig F $0,000<0,05$. Dengan demikian dapat disimpulkan bahwa Hipotesis pertama diterima yang berarti bahwa variabel bebas $\mathrm{X} 1, \mathrm{X} 2$ dan $\mathrm{X} 3$ secara serempak (simultan) berpengaruh positif dan signifikan terhadap variabel tidak bebas (Y).

Dengan demikian maka hipotesis pertama yang menyatakan bahwa: disiplin kerja, kompetensi dan produktivitas secara simultan berpengaruh positif dan signifikan terhadap kepuasan kerja pada Komisi Pemilihan Umum (KPU) Provinsi Sulawesi Tengah berdasarkan Uji F ternyata terbukti.

Pengujian Hipotesis Kedua, Ketiga dan Keempat

Pengujian secara parsial dimaksudkan untuk melihat pengaruh masing-masing variabel bebas $(\mathrm{X} 1, \mathrm{X} 2$ dan $\mathrm{X} 3)$ terhadap variabel tidak bebas (Y) sebagai berikut:

\section{Hipotesis Pengaruh disiplin kerja terhadap kepuasan kerja}

Untuk variabel disiplin kerja, hasil perhitungannya menunjukan bahwa nilai koefisien regresi sebesar 0,530 dan tingkat signifikasi sebesar $0,04<0,05$ atau $t_{\text {hitung }} 2,078>t_{\text {tabel }}$ 2,018 pada tarap kepercayaan $95 \%$. Sehingga dapat disimpulkan bahwa Hipotesis kedua diterima yang berarti bahwa disiplin kerja berpengaruh positif dan signifikan terhadap kepuasan kerja pada Komisi Pemilihan Umum (KPU) Provinsi Sulawesi Tengah. Dengan demikian maka hipotesis kedua yang menyatakan bahwa: disiplin kerja berpengaruh positif dan signifikan terhadap kepuasan kerja pada Komisi Pemilihan Umum (KPU) Provinsi Sulawesi Tengah berdasarkan Uji-t ternyata terbukti.

\section{Hipotesis Pengaruh kompetensi terhadap kepuasan kerja}

Untuk variabel kompetensi, hasil perhitungannya menunjukan bahwa nilai koefisien regresi sebesar 0,134 dan tingkat signifikasi sebesar $0,354>0,05$ atau $t_{\text {hitung }} 0,936<t_{\text {tabel }}$ 2,018 pada tarap kepercayaan 95\%. Sehingga dapat disimpulkan bahwa hipotesis ketiga ditolak yang berarti bahwa kompetensi berpengaruh positif namun tidak signifikan terhadap kepuasan kerja pada Komisi Pemilihan Umum (KPU) Provinsi Sulawesi Tengah. Dengan demikian maka hipotesis ketiga yang menyatakan bahwa: Kompetensi berpengaruh positif dan signifikan terhadap kepuasan kerja pada Komisi Pemilihan Umum (KPU) Provinsi Sulawesi Tengah berdasarkan Uji-t ternyata tidak terbukti.

\section{Hipotesis Pengaruh produktivitas terhadap kepuasan kerja}

Untuk variabel produktivitas, hasil perhitungannya menunjukan bahwa nilai koefisien regresi sebesar 0,968 dan tingkat signifikasi sebesar $0,000<0,05$ atau $t_{\text {hitung }} 6,476>t_{\text {tabel }}$ 2,018 pada tarap kepercayaan $95 \%$. Sehingga dapat disimpulkan bahwa hipotesis keempat diterima yang berarti bahwa produktivitas berpengaruh positif dan signifikan terhadap kepuasan kerja pada Komisi Pemilihan Umum (KPU) Provinsi Sulawesi Tengah. Dengan demikian maka hipotesis keempat yang menyatakan bahwa: produktivitas berpengaruh positif dan signifikan terhadap kepuasan kerja pada Komisi Pemilihan Umum (KPU) Provinsi Sulawesi Tengah berdasarkan Uji-t ternyata terbukti.

\section{PEMBAHASAN HASIL PENELITIAN}

Berdasarkan hasil pengujian hipotesis yang telah dilakukan, selanjutnya akan dilakukan pembahasan hasil dari analisis atas pengaruh disiplin kerja kompetensi dan produktivitas terhada kepuasan kerja pada Komisi Pemilihan Umum (KPU) Provinsi Sulawesi Tengah. Dari hasil pengujian terlihat dengan jelas bahwa secara parsial ada dua variabel yang berpengaruh positif namun tidak signifikan tehadap kepuasan kerja pada Komisi Pemilihan Umum (KPU) Provinsi Sulawesi Tengah yakni disiplin kerja dan kompetensi yang artinya bahwa semakin baik 
disiplin kerja dan kompetensi yang dimiliki akan memberikan pengaruh namun tidak taraf signifikan pada Komisi Pemilihan Umum (KPU) Provinsi Sulawesi Tengah yang tentunya akan berimplikasi terhadap tingginya tingkat kepuasan pegawai. sedangkan berdasarkan pengujian hipotesis pengaruh produktivitas terhadap kepuasan kerja diperoleh hasil bahwa produktivitas berpengaruh secara parsial terhadap kepuasan kerja yang artinya secara parsial produktivitas mempengaruhi secara langsung tingkat kepuasan kerja. Penjelasan pengaruh variabel $\mathrm{X}$ terhadap $\mathrm{Y}$ baik secara simultan maupun parsial adalah sebagai berikut:

1. Pengaruh disiplin kerja kompetensi dan produktivitas pada Komisi Pemilihan Umum (KPU) Sulawesi Tengah

Berdasarkan analisis hasil uji regresi diketahui bahwa variabel disiplin kerja kompetensi dan produktivitas berpengaruh positif dan signifikan terhadap kepuasan kerja pada Komisi Pemilihan Umum (KPU) Provinsi Sulawesi Tengah, ini berarti hipotesis pertama terbukti kebenaranya dimana disiplin kerja kompetensi dan produktivitas secara keseluruhan berada pada tanggapan yang baik dan tentunya diperlukan adanya peningkatan secara kualitas maupun kuantitas, sehingga diharapakan terhadap kepuasan kerja akan semakain baik dan semakin meningkat.

Hal ini didukung oleh beberapa pendapat tentang ketiga variabel yang diteliti antara lain dsiplin kerja, kompetenti dan Produktivitas kerja. Disiplin merupakan sikap, tingkah laku dan perbuatan yang sesuai dengan peraturan perusahaan baik yang tertulis maupun yang tidak tertulis. Peraturan yang dimaksud termasuk absensi, lambat masuk, serta cepat pulang karyawan. Jadi hal ini merupakan suatu sikap indisipliner karyawan yang perlu disikapi dengan baik oleh pihak manajemen. Banyak yang mengartikan disiplin itu bilamana karyawan selalu datang serta pulang tepat pada waktunya. Pendapat itu hanya salah satu yang dituntut oleh organisasi. Oleh karena itu kedisiplinan dapat diartikan sebagai tingkah laku yang tertulis maupun yang tidak tertulis. (Hasibuan, 2009:212). Sedangkan kompetensi adalah kombinasi dari motif, sifat, keterampilan, aspek citra diri seseorang atau peran sosial, atau suatu bagian dari pengetahuan yang relevan. Dengan kata lain, kompetensi adalah setiap karakteristik individu yang mungkin terkait dengan kesuksesan kinerja (Boyatzis, 1982, dalam Catano, 1998).

Sedangkan Sedarmayanti, 2001:57) mengemukakan bahwa produktivitas adalah bagaimana menghasilkan atau meningkatkan hasil barang dan jasa setinggi mungkin dengan memanfaatkan sumber daya secara efisien.

Dengan demikian, berdasarkan penelitian ini bahwa untuk meningkatkan kepuasan kerja Pada Komisi Pemilihan Umum (KPU) Provinsi Sulawesi Tengah diperlukan peningkatkan pada aspek kedisiplinan, kompetensi serta peningktan produktivitas sehingga mampu melahirkan hasil pekerjaan yang efektif dan efisien serta mampu memberikan nilai positif terhadap eksistensi organisasi dalam hal ini adalah Komisi Pemilihan Umum (KPU) Provinsi Sulawesi Tengah yang merupakan organisasi publik.

2. Pengaruh disiplin kerja terhadap kepuasan kerja pada Komisi Pemilihan Umum (KPU) Provinsi Sulawesi Tengah

Berdasarkan analisis hasil uji regresi diketahui bahwa variabel disiplin kerja berpengaruh positif dan signifikan terhadap kepuasan kerja pada Komis Pemilihan Umum (KPU) Provinsi Sulawesi Tengah. Hal ini menandakan bahwa hipotesis kedua terbukti dan berada pada tingkat penilaian yang sangat baik. Disiplin dalam bekerja merupakan faktor yang harus pula dimiliki oleh pegawai yang menginginkan tercapainya kepuasan dalam pekerjaannya. Disiplin kerja dapat berupa ketepatan waktu dalam kerja, ketaatan terhadap tugas-tugas yang diberikan kepadanya, serta pemanfaatan sarana secara baik. Pada dasarnya seluruh pegawai pada Komisi Pemilihan Umum (KPU) Provinsi Sulawesi Tengah memiliki tingkat disiplin kerja yang baik meskipun masih kurang disiplin dalam menjalankan tugas dan tanggung jawabnya sebagai pegawai, hal ini dapat dilhat dari hasil jawaban atas peryataan-pernyataan yang diberikan dalam penelitian ini, beberap penyataan yang cendrung memilih kurang setuju seperti mengerjakan tugas yang menjadi taggung jawab dan mengunakan jam kerja dengan baik dimana kedua pernyataan ini memiliki frekuensi jawaban yang cukup tinggi dari seluruh jumlah responden pada penelitian ini yang mengindikasikan bahwa pegawai pada KPU provisni Sulawesi Tengah masih memiliki sikap yang kurang disiplin terutama pada pengunaan jam kerja akan tetapi secara keseluruhan tingkat disiplin pada pegawai pada tarap yang baik. Hal ini sejalan dengan 
pendapat Sutrisno, (2009:94) yang mengemukakan bahwa disiplin pegawai adalah perilaku seseorang yang sesuai dengan peraturan, prosedur kerja yang ada atau disiplin adalah sikap, tingkah laku dan perbuatan yang sesuai dengan peraturan dari organisasi baik

Hasil ini sejalan dengan penelitian Ekayanti (2015) yang hasilnya menyatakan disiplin kerja berpengaruh positif dan signifikan terhadap kepuasan kerja. Semakin tinggi disiplin kerja yang diterapkan maka semakin meningkat kepuasan yang dirasakan karyawan.

3. Pengaruh kompetensi terhadap kepuasan kerja pada Komisi Pemilihan Umum (KPU) Provinsi Sulawesi Tengah

Berdasarkan analisis hasil uji regresi diketahui bahwa variabel kompetensi berpengaruh namun tidak signifikan terhadap kepuasan kerja pada Komisi Pemilihan Umum (KPU) Provinsi Sulawesi Tengah. Hal tersebut menunjukan bahwa hipotesis kedua tidak terbukti sebab berdasarkan hasil perhitungannya menunjukan bahwa nilai signifikan dari kompetensi diatas nilai t

Menurut (Spencer \& Spencer, 1993). Kompetensi adalah karakteristik yang mendasari individu yang kausal berkaitan dengan kinerja yang efektif dan/atau superior kriteria direferensikan dalam pekerjaan atau situasi. Sedangkan menurut (Linkage, Inc., 1996: 5, dalam Catano, 1998). Kompetenti adalah Pola karakteristik dan terukur pengetahuan, keterampilan, perilaku, keyakinan, nilai-nilai, sifat dan motif yang mendasari, dan kemampuan kerja yang cepat dalam mengaplikasikan pekerjaan

Berdasarkan uraian di atas, maka hasil ini sejalan dengan penelitian Justisia Iriani Rudlia (2016), menyatakan bahwa variabel kompetensi berpengaruh secara tidak signifikan terhadap variabel kepuasan kerja. Jika dilihat berdasarkan rata-rata tingkat pendidikan pegawai cukup tinggi dimana lebih dari 50\% telah mengenyam pendidikan hingga bangku kuliah, namun ternyata hal itu tidak terlalu memberikan pengaruh yang signifikan terhadap kepuasan kerja Pegawai. Pemilihan pegawai berdasarkan kompetensi yang dimilikinya belum sepenuhnya diterapkan. Penempatan seorang pegawai untuk mengisi suatu posisi tidak semata-mata berdasarkan hasil kerja atau kompetensi yang dimiliki seorang pegawai sehingga ada tidaknya kompetensi yang dimiliki seorang pegawai tidak terlalu mempengaruhi terhadap kepuasan kerja pegawai. i. Pengaruh produktivitas terhadap kepuasan kerja pada Komisi Pemilihan Umum (KPU) Provinsi Sulawesi Tengah

Berdasarkan analisis hasil uji regresi diketahui bahwa variabel produktivitas berpengaruh positif dan signifikan terhadap kepuasan kerja pada Komisi Pemilihan Umum (KPU) Provinsi Sulawesi Tengah, ini berarti hipotesis pertama terbukti kebenaranya dimana produktivitas secara keseluruhan berada pada tanggapan yang baik dan tentunya diperlukan adanya peningkatan secara kualitas maupun kuantitas, sehingga diharapakan dapat meningkatkan kepuasan kerja yang akan semakain baik dan semakin produktif. Hal tersebut juga menunjukan bahwa pegawai pada Komisi Pemilihan Umum (KPU) Provinsi Sulawesi Tengah semakin puas terhadap kinerjanya selama ini, dengan kata lain bahwa produktivitas lebih di tingkatkan maka akan perimplikasi kepada tingginya tingkat kepuasan kerja pada Kantor Komisi Pemilihan Umum (KPU) Provinsi Sulawesi Tengah.

Sejalan dengan Simamora (2004: 612) yang menyatakan bahwa faktor-faktor yang digunakan dalam pengukuran produktivitas kerja/indikator produktivitas meliputi kuantitas kerja, kualitas kerja dan ketepatan waktu:Kuantitas kerja adalah merupakan suatu hasil yang dicapai oleh karyawan dalam jumlah tertentu dengan perbandingan standar ada atau ditetapkan oleh perusahan. Kualitas kerja adalah merupakan suatu standar hasil yang berkaitan dengan mutu dari suatu produk yang dihasilkan oleh karyawan dalam hal ini merupakan suatu kemampuan karyawan dalam menyelesaikan pekerjaan secara teknis dengan perbandingan standar yang ditetapkan oleh perusahaan. Ketepatan waktu merupakan tingkat suatu aktivitas diselesaikan pada awal waktu yang ditentukan, dilihat dari sudut koordinasi dengan hasil output serta memaksimalkan.

\section{KESIMPULAN DAN REKOMENDASI Kesimpulan}

Bedasarkan hasil analisis dan pembahasan pada bab sebelumnya, maka kesimpulan penelitian ini adalah:

1. Disiplin Kerja, kompetensi dan Produktivitas secara simultan berpengaruh positif terhadap kepuasan kerja pada Komisi Pemilihan Umum (KPU) Provinsi Sulawesi Tengah. 
2. Disiplin kerja secara parsial berpengaruh positif terhadap kepuasan kerja pada Komisi Pemilihan Umum (KPU) Provinsi Sulawesi Tengah

3. Kompetensi secara parsial berpengaruh positif namun tidak signifikan terhadap kepuasan kerja pada Komisi Pemilihan Umum (KPU) Provinsi Sulawesi Tengah

4. Produktivitas secara parsial berpengaruh positif terhadap kepuasan kerja pada Komisi Pemilihan Umum (KPU) Provinsi Sulawesi Tengah

\section{Saran-saran}

Untuk meningkatkan kepuasan kerja pada Komisi Pemilihan Umum (KPU) Provinsi Sulawesi Tengah, penulis menyarankan beberapa hal yang perlu disikapi oleh pimpinan sebagai berikut:

Untuk memberikan dan meningkatkan kepuasan kerja, pimpinan ataupun pejabat berwenang perlu merumuskan kebijakan yang mengedepankan :

1. Penigkatan disiplin kerja terhadap pegawai antara lain yang berkaitan dengan kehadiran, bertanggung jawab terhadap tugas yang menjadi beban kerja serta pengunaan jam kerja seefisien mungkin pada Komisi Pemilihan Umum (KPU) Provinsi Sulawesi Tengah.

2. Peningkatan kompetensi pada pegawai khususnya yang berkaitan dengan keterampilan mejalankan tugas, mengelola tugas serta keterampilan dalam mengambil keputusan kerja pada Komisi Pemilihan Umum (KPU) Provinsi Sulawesi Tengah.

3. Peningkatan produktivitas pegawai maka diperlukan perbaikan pada sektor kuantitas kerja serta ketepatan waktu dalam menyelesaikan tugas pada Komisi Pemilihan Umum (KPU) Provinsi Sulawesi Tengah.

4. Bagi peneliti lanjutan, disaranakan untuk menambahkan variabel lain seperti variabel intervening sehingga penelitian ini akan menjadi lebih akurat dengan tingkat pendekatan yang berbeda sehingga dapat menambah khasana pengetahuan serta membantu dalam proses penelitian selanjutnya.

\section{DAFTAR RUJUKAN}

Azis, A. (2019). PENGARUH FASILITAS, KEMAMPUAN DAN DISIPLIN KERJA TERHADAP KINERJA PEGAWAI KANTOR KECAMATAN TINOMBO KABUPATEN PARIGI MOUTONG. Jurnal Ekonomi Trend, 7(2), 30-41. https://doi.org/10.31970/trend.v7i2.178

Catano, V. 1998. Competencies: A Review of the Literature and Bibiliography. Canadian council of Human Resources Associations.

Ekayanti, Ni PutuYuni. 2015. Pengaruh Stres Kerja dan Disiplin Kerja Ter-hadap Kepuasan Kerja dan Kinerja Pegawai Negeri Sipil (PNS) di Ling-kungan Kecamatan Denpasar Selatan Kota Denpasar. Tesis UNWAR Denpasar.

Hasibuan, Malayu S.P. 2001. Manajemen Sumber Daya Manusia:Pengertian. Dasar, Pengertian, dan Masalah. PT. Bumi Aksara, Jakarta.

Hasibuan, Malayu S.P. 2005. Manajemen Sumber Daya Manusia, Edisi Revisi. Bumi Aksara, Jakarta.

2006, Manajemen Dasar, Pengertian, dan. Masalah,Edisi Revisi, Bumi Aksara:Jakarta.

2009. Manajemen: Dasar. Pengertian, dan Masalah. Edisi Revisi. Jakarta : Bumi Aksara.

Moeheriono. 2009. Pengukuran Kinerja Berbasis Kompetensi. Bogor: Ghalia Indonesia.

Rahman, A. (2019). PENGARUH HUBUNGAN INTERPERSONAL, LINGKUNGAN KERJA, DAN KECERDASAN EMOSIONAL TERHADAP KINERJA PEGAWAI PADA KANTOR KOMISI PEMILIHAN UMUM DAERAH (KPUD) KABUPATEN PARIGI MOUTONG. Jurnal Ekonomi Trend, 7(1), 58-70. https://doi.org/10.31970/trend.v7i1.173 
Rudlia, Iriani Justisia. 2016, Pengaruh Kompetensi dan Kompensasi terhadap Kepuasan Kerja dan Kinerja Pegawai (Studi Kasus Pada Dinas Kelautan dan Perikanan Kabupaten Kepulauan Sangihe Jurnal 2016

Salim, F. U. (2019). PENGARUH MOTIVASI DAN KOMPETENSI TERHADAP KINERJA PEGAWAI NEGERI SIPIL SEKRETARIAT DEWAN PERWAKILAN RAKYAT DAERAH (DPRD) PROPINSI SULAWESI TENGAH. Jurnal Ekonomi Trend, 7(2), 12-18.

https://doi.org/10.31970/trend.v7i2.176

Sastrohadiwiryo, Siswanto. 2003, Manajemen Tenaga Kerja Indonesia, edisi. 2, Jakarta, PT. Bumi Aksara.

Siagian, Sondang, P. 1999. Manajemen Sumber Daya Manusia. Jakarta: Bumi Aksara.

Sedarmayanti. 2001. Sumber Daya Manusia dan Produktivitas Kerja. Bandung: Mandar Maju.

Simamora, Henry. 2004, Riset Pemasaran, Gramedia Utama, Jakarta.

Spencer, Lyle \& Signe M. Spencer. 1993. Competence at Work, Models For Superior Performance. Canada : John Wiley \& Sons, Inc.

Sugiyono, 2010. Metode Penelitian Kuantitatif Kualitatif dan Kombinasi. Bandung: Alfabeta.

Sutrisno, Edi. 2009. Manajemen Sumber Daya Manusia Edisi pertama. Jakarta: Kencana Prenada Media Group.

Supranto, J. 2000. Pengukuran Tingkat Kepuasan Pelanggan Untuk Menaikkan Pangsa Pasar. Rineke Cipta: Jakarta.

Riduwan, 2003, Dasar-Dasar Statistika, Cetakan Ketiga, Bandung : Alfabeta.

Umar, Husein. 2005. Riset Sumber Daya Manusia Dalam Organisasi, Di PT. Gramedia Pustaka Utama, Jakarta.
Umar A, M. (2019). STRATEGI PEMASARAN DALAM UPAYA PENINGKATKAN VOLUME PENJUALAN PERUSAHAAN COMFORTA PALU. Jurnal Ekonomi Trend, 7(1), 27-40. https://doi.org/10.31970/trend.v7i1.171 